Antonio Pagés Larraya

\title{
Urge retomar el diálogo americano que continúe el espiritu de otras etapas de trascendencia creadora
}

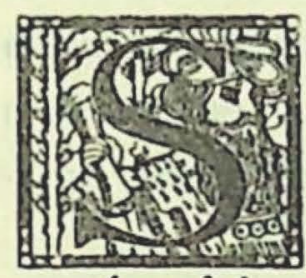

ARMIENTO y el chileno Lastarria se conocieron en enero de 1841. Proscripto, pobre, con el dolor de haber visto a su tierra avasallada por la tiranía, sin planes concretos para el futuro, Sarmiento, a los treinta años, se sentía viejo. Atravesaba una de esas crisis tremendas de las almas señeras. "Joven viejo" le llamaba Lastarria en sus Recuerdos Literarios. A Lastarria, en cambio, todo le sonreía: contaba sólo. veinticuatro años, era ya catedrático del Instituto Nacional y un joven maestro de su generación. La silueta que traza del sanjuanino está llena de simpatía y de realidad. Ve en la fisonomía de Sarmiento "los destellos de un gran espíritu" y elogia su talento para "embellecer con la palabra sus formas casi' de gaucho".

El genio sistemático de Lastarria - formado a través de estudios serios y hondos - enfrentaba con cierto asombro el ardor lleno de aristas del autodidacto genial. Comenzó aś una amistad intensísima, tejida de coincidencias profundas y de oposiciones violentas. Dunrante muchos años se trataron asiduamente y durante cuarenta y cuatro (de 1844 a 1888) se escribieron. Recordemos una de las cartas de esa correspondencia que en 1954 editó y comentó María Luisa 
del Pino Carbone. Se trata de la que escribe Lastarria a Sarmiento el 22 de octubre de 1868 con motivo de la exaltación del amiga a la presidencia de la República. El chileno se alegra del acontecimiento y le parece que hará época en la historia del continente. "Vuestra gloria es la gloria de los obreros de la inteligencia en América”, le dice quien había participado de sus pesares y de sus triunfos y conocía bien la garra del autor de Facundo.

Frente al deprimente espectácula de otros países americanos que oscilaban entre la ignorancia y el despotismo, la elección de Sarmiento asume para Lastarria una proyección continental:

"Vuestra patria, en los conflictos de una guerra exterior y de una conflagración interna, se ha echado en brazos de un maestro de escuela, de un obrero de la idea, de un representante del progreso intelectual; esto consuela y da fe a los que esperamos y perseveramos en la democracia". ¡Una nación en brazos de un maestro de escuela! Maestro era también Lastarria y por eso en la misma carta le habla de un texto suyo y se excusa de tratar asuntos menores en ocasión tan solemne, aunque con la advertencia de que "un presidente americano debe entender en todas esas menudencias".

Nobles ideas, ardorosas discrepancias y constructivas "menudencias" campean en las cartas de estos "obreros de la inteligencia en América".

El futuro de la democracia en pueblos castigados por las plagas del caudillismo, de la demagogia o de los planes brillantes sin engarce con la realidad, es el gran tema del cuyano ciclópeo y del eximio chileno que se escribieron durante cuarenta y cuatro años...

Análisis profundos o simples referencias que atañen a nuestras tradiciones, nuestra política, nuestro progreso, aparecen constantemente en esas cartas. Ellas constituyen tan sólo parte del gran diálogo americano en el que participaban tantos otros hijos de nuestro suelo. Proscriptos por la tiranía, levantaban en tierras hermanas las bases espirituales del renacimiento americano.

Una patria fuimos durante las guerras de la independencia. Una patria seguimos siendo en los tristes y largos años de la opresión. El 
dolor y el sacrificio exaltan la fraternidad auténtica. Después... Nuestras instituciones se afianzaron y la seducción de culturas más eminentes y antiguas nos fue alejando y pasó a segundo plano o se extenuó el intenso coloquio.

En 1882, con motivo del proyecto de un Congreso Literario Latinoamericano que por entonces se debatía, Ernesto Quesada analiza las desvinculaciones de naciones unidas por rasgos comunes: "Es increíble el extraordinario aislamiento intelectual de los países latinoamericanos entre sí: vivimos como si nos encontráramos en los polos opuestos de la tierra, ignorando el estado de los conocimientos en uno y otro país, y sin conocer ni lo que se publica ni lo que se trabaja ni lo que entre nosotros se estudia".

Quesada reclama a los hombres del 80 una actitud de simpatía que recupere el ritmo cordial de antes, el intercambio de ideas, de libros, de proyectos. Quien lea hoy completo el estudio de Quesada y las soluciones para superar el aislamiento de los pueblos hispanoamericanos, verá hasta qué punto las sugestiones del ayer pueden resultar actuales.

El restablecer el diálogo - con el tono y la sinceridad que en la correspondencia de Sarmiento y Lastarria campea- ensanchará la resonancia del' escritor americano y le ayudará a enriquecer, en nuevas perspectivas, la proyección de su tarea. Legados del ayer, creaciones del presente, proyectos para el porvenir, serán así partes vitales de una cultura fértil, comunicada, con aliento universal y la peculiar expresión del Nuevo Mundo. 